Waste and Resource Management Volume 167 Issue WR2

Industrial network design by improving construction logistics

Tischer, den Boer, Williams and Curran
Proceedings of the Institution of Civil Engineers Waste and Resource Management 167 May 2014 Issue WR2 Pages 82-94 http://dx.doi.org/10.1680/warm.13.00025 Paper 1300025

Received 20/07/2013 Accepted 24/01/2014

Published online 25/03/2014

Keywords: logistics/recycling \& reuse of materials/waste

management \& disposal ice

Institution of Civil Engineers

\title{
Industrial network design by improving construction logistics
}

1 André Tischer Dipl

Project Assistant, bauserve GmbH, Frankfurt, Germany; Research and Teaching Assistant, University of Technology Darmstadt, Darmstadt, Germany

2 Emilia den Boer Mgr Inz, MSC, Dr Inz

Assistant Professor, Wroclaw University of Technology, Institute of Environment Protection Engineering, Wroclaw, Poland
3 Ian Williams PhD, PGCE, CChem, MRSC, MCIWM, FHEA Professor, Centre for Environmental Sciences, Faculty of Engineering and the Environment, University of Southampton, Southampton, UK

4 Tony Curran MRes, PhD, LCGl

Research Fellow, Centre for Environmental Sciences, Faculty of Engineering and the Environment, University of Southampton, Southampton, UK
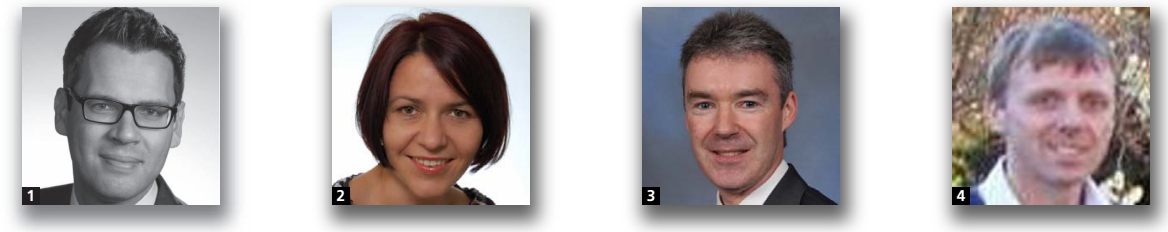

Implementing an industrial network in the construction industry can be achieved by changing construction management activities directly on the construction site within the design and operation phase. Construction logistics plays a crucial role here, in particular on the downstream side where waste has to be efficiently collected, separated, sorted and, finally, transported from site to different waste management options. The objective of this paper is to introduce an approach for efficient construction logistics that can ensure successful implementation of an industrial network in the construction industry from the point of view of on-site materials management within the logistics of disposal. Two construction projects in Germany were investigated and it was found that the total number of material streams separated directly on site in each project could be increased from 1 to 7 and from 1 to 19 different fractions. The study also revealed that the reuse and recycling rate could be increased to over $75 \%$ in both projects and the total costs of construction logistics could also be reduced. It was thus possible to increase material resource efficiency on the downstream side for both construction projects - by $43 \%$ in project I and by $68 \%$ in project II.

\section{Introduction}

The bulk of material resources used in the modern European economy end up as materials that accumulate in the economy. The rest, however, are converted into emissions or waste (EEA, 2012). Although Europe has become more efficient in managing material resources over the past years, there is still a need to improve resource efficiency as a major step towards a 'recycling society' (EEA, 2012). However, an efficient economy can only be achieved with a considerable change in consumption, especially in production patterns (EEA, 2012), moving away from a 'throwaway' society towards a society that thinks in 'closed material loops'. The construction industry plays a crucial role here, as construction and demolition waste (CDW) represent a large part of total waste generation in Europe (Figure 1) and have a high potential for reuse and recycling (Brodersen et al., 2002).

Improving resource efficiency in the construction industry by focusing on construction management on site and in its regional activities could be implemented by designing and implementing an industrial network around a construction site. In general, such a network is regarded as an organisational setting at a regional level where the main principles of industrial ecology find application (Mirata and Pearce, 2006). The network could offer a potential, for instance, for

anvironmental benefits linked to reductions in resource use, pollutant emissions and waste handling needs

- economic benefits from reduction of the costs of resource inputs and/or waste management and from generation of additional income due to higher value of by-products and waste for recovery

- business benefits due to improved relationships with external parties or development of a green image

social benefits by generating cleaner, safer, natural working environments (Mirata and Pearce, 2006).

Although this potential is desirable for contributing to a growth in efficiency, the number of functional, comprehensive 


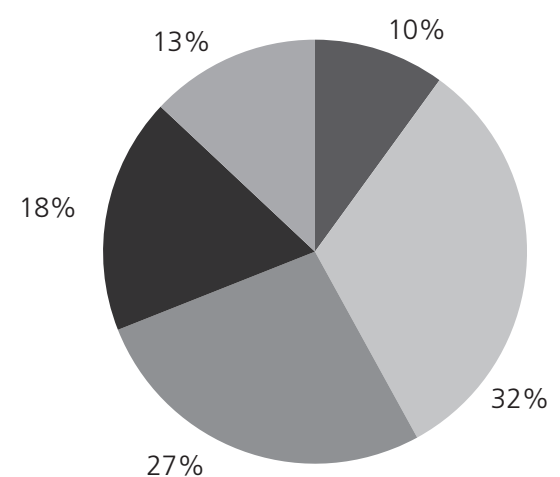

Figure 1. Total waste generation in the EU, EFTA (Norway, Switzerland, Iceland and Liechtenstein), Turkey and Croatia in 2008 (EEA, 2010)
Waste from households (10\%)

Construction and demolition waste (32\%)

Mining and quarrying waste (27\%)

- Other wastes (18\%)

Manufacturing wastes excluding recycling (13\%) examples of industrial networks in the construction industry is low. This is mostly attributed to the fact that the industry is considered to be diversified and fragmented, where construction parties pay most attention to conforming to their own contractual requirements (Cheng et al., 2001) rather than getting involved in additional inter-branch tasks. In consequence, processes within the design phase, but especially within the operating phase, typically run inefficiently and prevent the implementation of an industrial network. This applies to the processes of construction logistics in general, but in particular to the logistics of disposal dealing with waste management on site. Indeed, construction sites are characterised by a high rate of mixed CDW, which leads to higher disposal rates or - in the best case - energy recovery from combustible waste, thus preventing the reuse and recycling of material directly from the site. Indeed, in Germany, the industrial waste ordinance GewAbfV (BBD, 2003) merely requires producers and owners of CDW to separate, store and separately collect only four waste fractions - glass, plastics, mixed metals, and mixtures of concrete, bricks and tiles. The regulation also allows that these fractions can be collected comingled as long as they are supplied to a pre-treatment facility that ensures the clean sorting of these fractions. It is thus legally allowable to collect on-site mixed CDW (without any hazard waste fractions) when ensuring separation of these four fractions at a sorting plant.

In order to secure smooth on-site waste management and enable the establishment of an industrial network around a site, alternative approaches concerning construction logistics could be applied. This especially concerns waste management on site within the logistics of disposal. An adequate and optimal construction logistics plan can be key to an effective and efficient implementation of material and waste flows on site during construction (Hasenclever et al., 2011; Tischer et al., 2013a).
There is, however, little or no reported research into understanding and measuring the effects of construction logistics with respect to the application of an industrial network around a site. This particularly applies to the logistics of disposal. The paper aims to contribute to fill this gap, focusing on the analysis of on-site materials management within the logistics of disposal. The motivation of this research is to introduce an approach for efficient construction logistics to ensure the successful implementation of an industrial network in the construction industry, and two construction projects in Germany were investigated for this purpose.

The paper is organised as follows. First, a comprehensive overview of construction logistics, industrial network design, the case study methodology and eco-efficiency is presented. Then, the two construction projects in Germany are introduced, along with the concept of an efficient construction logistics model implemented at both sites. The results concerning the industrial network and resource efficiency investigated in the two projects are presented. The paper concludes with a summary and description of practical relevance and potential applications of the results.

\section{Methodology}

\subsection{Construction logistics}

In terms of industry-specific characteristics of logistics (Ebel, 2012; Krauß, 2005), construction logistics deals with the planning, operation and control of materials, personnel and information flows within a construction project (Schach and Schubert, 2009). The three areas of logistics of delivery, site logistics and logistics of disposal control the procurement and transportation of materials to and on site, the provision of materials, and the recovery and disposal of residual materials on site and from site (Boenert and Blömeke, 2003). 
Waste and Resource Management

Volume 167 Issue WR2
Industrial network design by improving construction logistics

Tischer, den Boer, Williams and

Curran
The planning and coordination of construction logistics is a difficult challenge, as companies are usually interested in their own supply chains on site (Voigtmann and Bargstädt, 2010). Traditionally, construction logistics tasks are performed by several different persons in different construction companies working on site, of whom only a few are occupied in the construction process itself. Thus, insufficiently planned and non-coordinated logistics processes are the consequence, and the reason for a high amount of non-productive actions and consequently disturbed work flow on site (Voigtmann and Bargstädt, 2010).

The efficient management of construction materials and waste planning tasks requires an integrated approach towards various logistical functions (Jang et al., 2003). Fundamental construction operations of facilities, inventory control and communication planning need to be closely coordinated (Jang et al., 2003). An efficient construction logistics approach for large-scale construction projects in Germany is introduced in Section 3.3 of this paper.

\subsection{Industrial network}

According to Williams and Curran (2010), there is no common definition of an industrial network, but Mirata and Pearce (2006) define an industrial network as an organisational setting at a regional level where the main principles of industrial ecology find applications. Some good practical examples of industrial networks, which often developed organically and with myriad objectives, are the municipality of Kalundborg in Denmark, the Kwinana industrial area in Western Australia and Fujisawa eco-industrial park in Japan (Williams and Curran, 2010). One of the main reasons for the establishment and success of such networks was that companies at a regional level could exchange their by-products.

Indeed, waste stemming from one production process cannot usually be reused or recycled in the same process, only within another process (Schwarzer and Steininger, 1997). If there is no suitable reutilisation process for the waste-producing enterprise, a network has to be firstly created by implementing integrated inter-company technologies and then expanded to include other companies (Schwarzer and Steininger, 1997). The prerequisite is that the participating companies provide a sufficient base for operation (i.e. all the individual partners 'match') (Schwarzer and Steininger, 1997). This means that, in particular terms of quality and quantity, the waste of one partner needs to be usable as a raw material for the other (Schwarzer and Steininger, 1997). Figure 2 presents the idea of establishing an industrial network in accordance with Williams and Curran (2010).

\subsection{Case study methodology}

In this work, a case study methodology was used as the main research method. This methodology is excellent for theory building, for describing 'best practices' in detail and for providing a greater understanding of the data gathered (Ellram, 1996; Kim

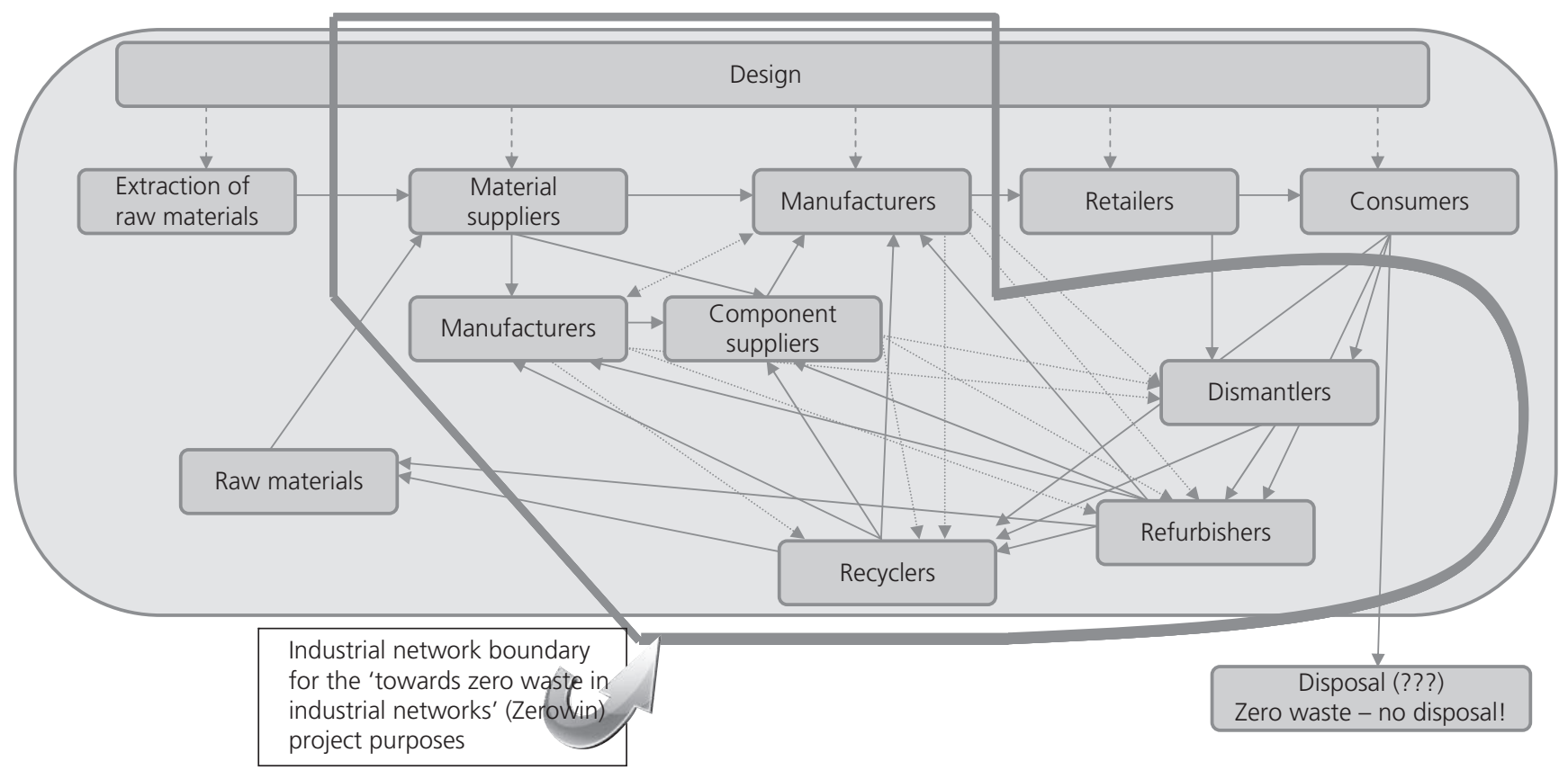

Figure 2. Proposal for the scope and boundary of an industrial network (Williams and Curran, 2010) 
and Min, 2012). Case study research enables a researcher to answer 'how' and 'why' type questions (Baxter and Jack, 2008). The methodology should be carefully planned in advance and should support systematic gathering of the data required to address the research questions of interest (Ellram, 1996). A thorough literature review is beyond the scope of this paper, thus readers are referred to academic research on case study methodology (e.g. Eisenhardt, 1989; Meredith, 1998; Yin, 2008).

This work used explorative qualitative and quantitative multicase research. The aim was to identify how an industrial network could be implemented around a site for two construction projects in Germany and if such a network is linked with an increase in material resource efficiency.

\subsection{Eco-efficiency}

The results of the progress achieved at the construction sites studied was evaluated and assessed by Obersteiner et al. (2013). Moreover, for these particular cases, the eco-efficiency method was applied. In general, a wide variety of terminology referring to eco-efficiency has developed in recent years, differing in its application, the background of the researchers or even in views on how to treat negative signs (Huppes and Ishikawa, 2005). As a result, the term eco-efficiency has been used in different ways and other terms used that overlapped with these meanings (e.g. environmental cost effectiveness and environmental productivity) (Huppes and Ishikawa, 2005).

The main aim from the point of view of construction logistics is to realise both cost-efficient and environmentally friendly material flows by integrating the logistics of delivery and the logistics of disposal. In particular, as the objective of this work was to analyse materials management on site within the logistics of disposal, the methodology described by Tischer et al. (2013b) was used to measure the eco-efficiency of waste management

$$
\text { 1. } \mathrm{EE}_{\mathrm{CLD} i}=\frac{\mathrm{RR}}{100 \%} \times \frac{1}{C_{\mathrm{CLD} i} / m_{\mathrm{wt}}}
$$

in which $\mathrm{EE}_{\mathrm{CLD} i}$ is the eco-efficiency of construction logistics of disposal (in $\mathrm{t} / €$ ), $\mathrm{RR}$ is the reuse and recycling rate (in $\%$ by weight) achieved in a construction project, $C_{\mathrm{CLD} i}$ is the absolute cost of construction logistics of disposal (in $€$ ) and $m_{\mathrm{wt}}$ is the total amount of waste produced on site in a construction project. The term $C_{\mathrm{CLD} i} / m_{\mathrm{wt}}$ can be defined as the relative cost of the logistics of disposal.

\section{Case studies}

\subsection{Project I: Refurbishment project}

The first project under investigation was a refurbishment project located in the Rhine-Main metropolitan region in Germany. As the greatest refurbishment of a building undertaken in Europe, the site area covered $13000 \mathrm{~m}^{2}$ with a building gross floor space of $122000 \mathrm{~m}^{2}$. The building site consisted of three base levels, divided into three sections with a total height of approximately $21 \mathrm{~m}$, as well as two high-rise towers. The total height of the towers amounted to around $155 \mathrm{~m}$. Both towers had three basement stories and were founded on a single floor slab with a depth of approximately $13 \mathrm{~m}$ below ground level.

The quantitative research was based on a complete set of data for the whole construction period (December 2007-February 2011). It was thus possible to observe how an industrial network could be implemented around the site and what benefits it would bring. It was also possible to investigate both the economics and efficiency of the implemented logistics concept on site.

\subsection{Project II: New construction project}

The second project investigated was a new construction project in Munich. One of the largest new construction projects in Germany, the site area is $35400 \mathrm{~m}^{2}$ with a building gross floor area of about $90000 \mathrm{~m}^{2}$ and floor space of about $65000 \mathrm{~m}^{2}$. Planned with an existing structure in mind, a new building complex with apartments, offices, shops, cultural and leisure facilities was proposed. Munich City Council decided to proceed with the project in July 2010 and preliminary construction commenced in 2011/12. All the units are expected to be ready for occupancy in 2015 .

The quantitative research for this project was based on an accurately estimated set of data that was prepared within the design phase of the project from 2011 onwards. It was thus possible to observe how an industrial network could be implemented within the design phase of a new construction project. As in project I, it was also possible to investigate both economic issues and the efficiency of the implemented concept on site.

\subsection{Implemented concept of efficient construction logistics}

For the two construction projects, the concept of efficient construction logistics was implemented on site for both the logistics of delivery and the logistics of disposal. The concept was introduced, in general, in previous works (Goetz and Höchsmann, 2010; Tischer and Gartmann, 2010; Tischer et al., 2013a, 2013b). The main characteristics are as follows.

\subsubsection{Planning phase - designing construction logistics} Starting within the planning phase of a project, the design of a construction logistics plan at an early stage was implemented as follows. First, all potentials and restrictions for the site regarding logistical aspects were identified. Then, in consultation with the building owner, the architects, the main contractor and local authorities, the framework conditions to 
Waste and Resource Management

Volume 167 Issue WR2
Industrial network design by

improving construction logistics

Tischer, den Boer, Williams and

Curran put a logistics system in place were determined, these being tailored to the particular needs of each actor. Finally, a handbook was created where all logistics aspects for the construction phase of the specific project were written down. This handbook was then used as a signed guideline for all the main contractors and subcontractors to fulfil their work in consideration of these logistical processes (Tischer and Gartmann, 2010).

\subsubsection{Operating phase - logistics of delivery}

The strategic process-oriented coordination of logistics was based on the optimisation and regulation of all transports to and on site. This was implemented as follows (Figure 3). Each executing company and contractor had to register, either manually or via online registration, its material delivery to site. Through a software-based interface, the companies selected the date, time and handling place on site for each delivery. When the material was delivered, the logistics service company ensured just-in-time handling and transportation of the material to the place of integration (Tischer et al., 2013b)

\subsubsection{Operating phase - logistics of disposal}

The logistics plan concerning disposal was implemented as follows (Figure 4). Right from the beginning of each project, the logistics service provider provided each executing company with moveable containers. The companies were thus able to collect their waste, separated into predefined categories. The logistics service provider was responsible for the transportation of different wastes to the collecting station on site, as well as the transport of the separated material fractions to refurbishing or recycling companies and manufacturers (Tischer et al., 2013a, 2013b).

\section{Results and discussion}

\subsection{Industrial network}

Table 1 shows the material changes that could be realised in total across both projects, based on an analysis of the resource exchange and material flows from construction site to different industries and project partners.

A total quantity of $37480 \mathrm{t}$ of $\mathrm{CDW}$ was produced on site across both projects. Due to on-site separation and recovery activities, $997 \mathrm{t}(2 \cdot 7 \%)$ of that amount could be reused as material for other construction sites, $27854 \mathrm{t}(74 \cdot 3 \%)$ could be recycled, $1163 \mathrm{t}(3 \cdot 1 \%)$ supplied to energy recovery and $7356 \mathrm{t}$ $(19 \cdot 6 \%)$ collected for backfilling recovery (Figure 5). However, during the demolition and gutting phase in project $\mathrm{I}, 111 \mathrm{t}$ $(0 \cdot 3 \%)$ of insulation materials containing asbestos had to be separated and delivered to landfill. In total, $10036 \mathrm{t}(26 \cdot 8 \%)$ of waste could be diverted from landfill, $2685 \mathrm{t}(7 \cdot 2 \%)$ from incineration and $4093 \mathrm{t}(10 \cdot 9 \%)$ from sorting plants (Figure 6).

Although the concept of efficient construction logistics was implemented in the same way for both projects through the logistics service provider together with the owner and the main contractors on each site, the network and its effectiveness (measured by the total number of material streams separated directly on site) differed between projects (Figure 7). In project I, 19 material fractions were separated and directly sorted on site for reuse and material recycling. Compared to the baseline scenario of just one material stream for recycling, it was possible to supply all these materials to different recyclers, manufacturers and refurbishers. In project II, it was estimated that seven material streams could be directly separated on site

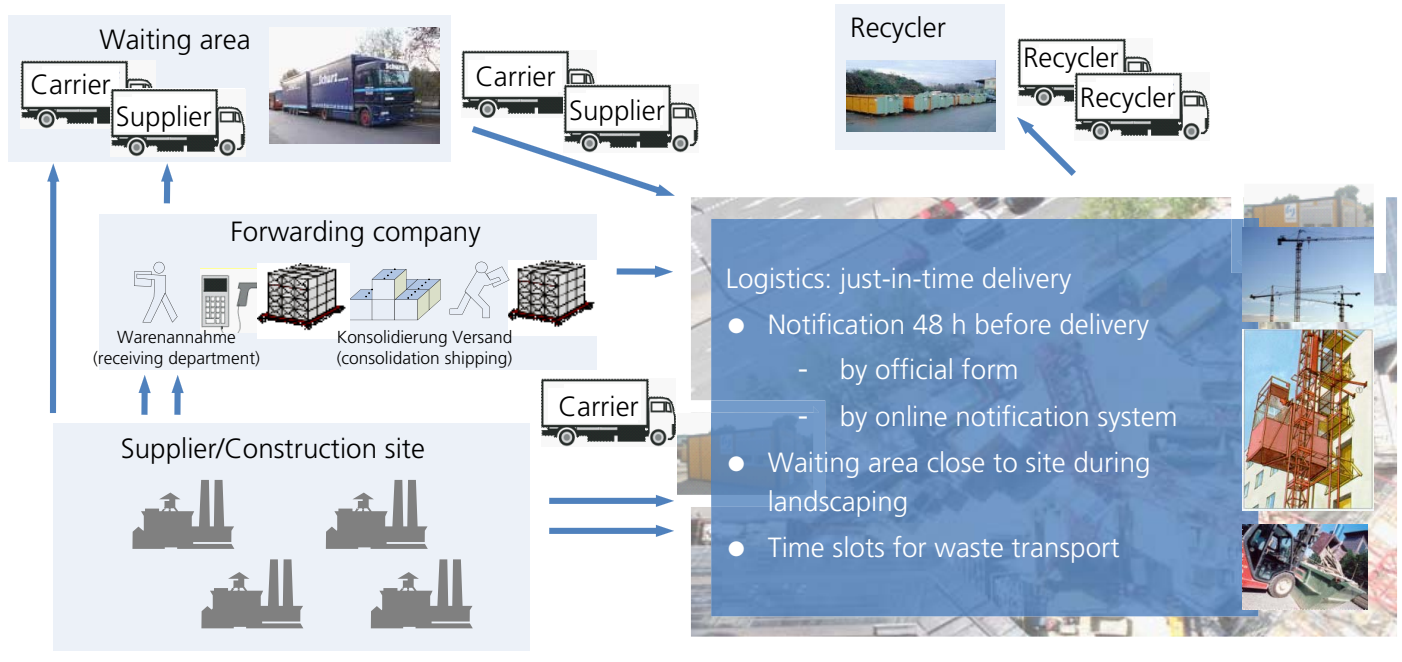

Figure 3. Procedure of logistics of delivery (Tischer et al., 2013b) 


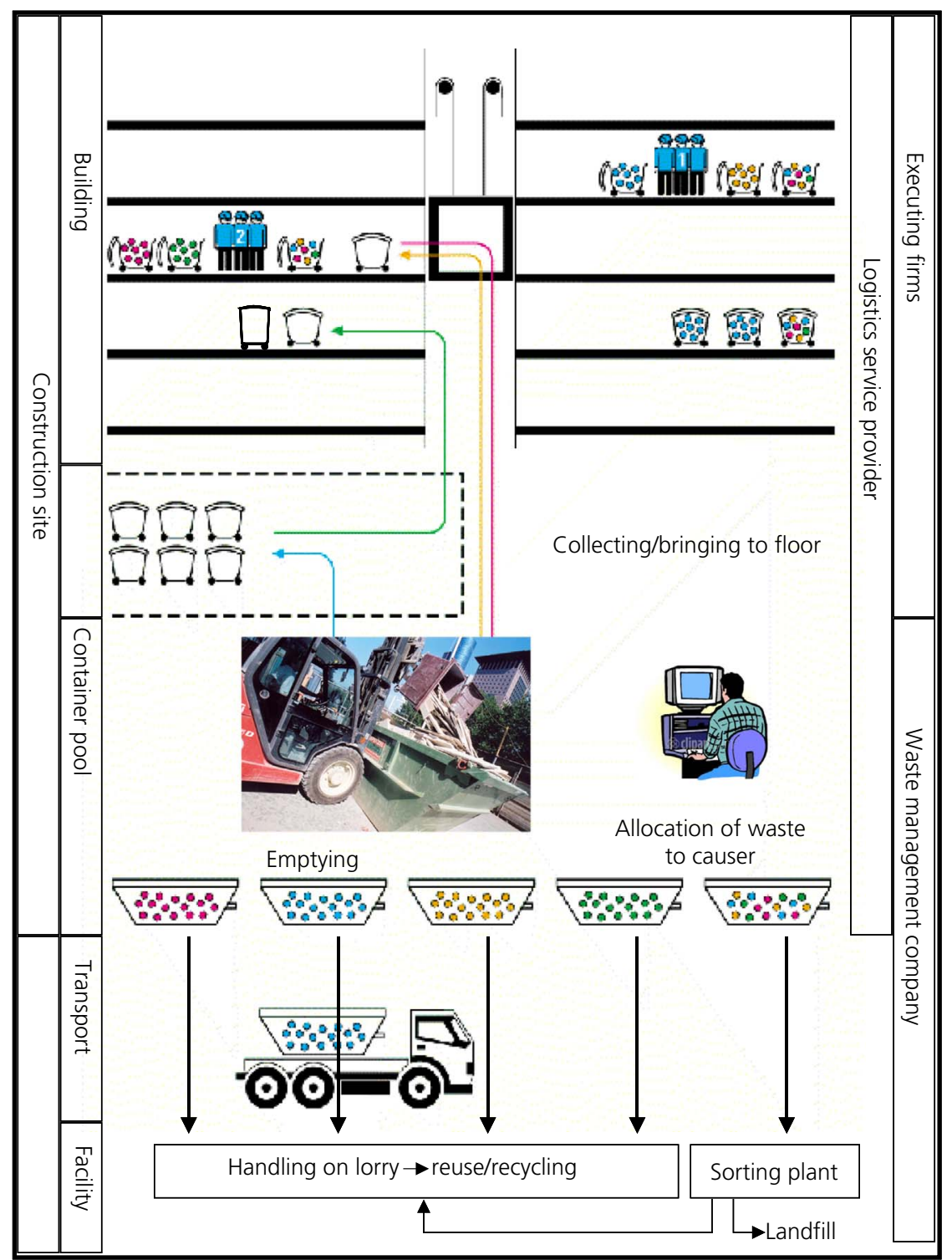

Figure 4. Procedure of logistics of disposal (Tischer et al., 2013b with permission of bauserve $\mathrm{GmbH}$ )

for material recycling, again representing a significant increase on the baseline scenario of just one material stream for recycling.

However, the question is raised of why the number of material fractions sorted on site in project II was much lower than in project I. Project I was a refurbishment project and most of the waste materials were collected and separated on site during the demolition and gutting phase. During the construction phase, when new materials were being delivered to site, 'just' eight material fractions were sorted and collected. This number is consistent with the results found in project II, which was new construction.

Another important factor was that the building owner of project I aimed to certify the project according to international sustainability systems, which impose high standards for the reuse and recycling rate of CDW. Finding project partners such as recyclers and manufacturers around the construction site for the majority of generated waste streams and documentation of these results was thus necessary to enable certification of the project (Tischer et al., 2013a, 2013b). 
Waste and Resource Management

Volume 167 Issue WR2
Industrial network design by

improving construction logistics

Tischer, den Boer, Williams and

Curran

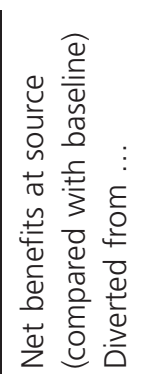

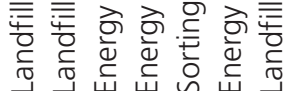

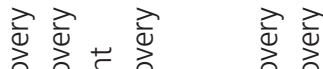

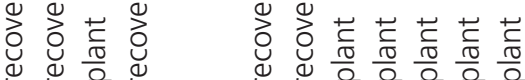

年

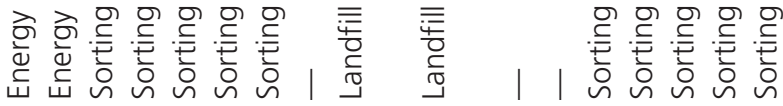

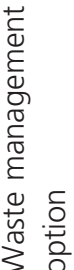

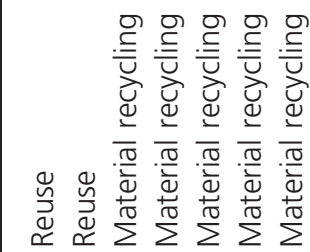

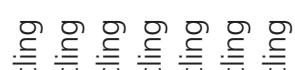

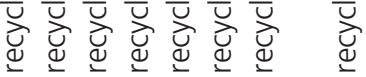

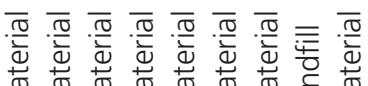

$\sum \sum^{\pi} \sum \sum^{\pi} \sum \sum^{\pi} \sum^{\pi} \sum \sum^{\pi} \frac{\pi}{\pi} \sum^{\pi}$

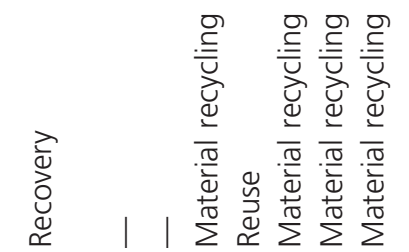

党 $\frac{0}{4}$

藏

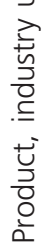

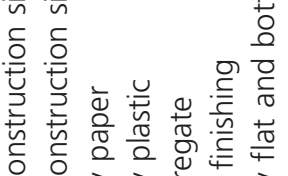

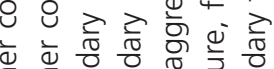

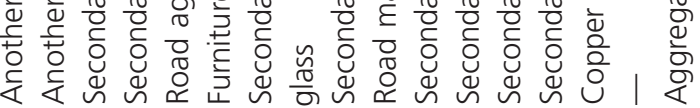

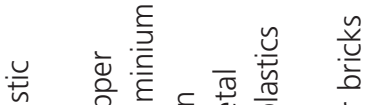

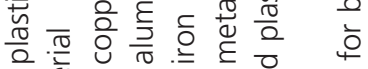

20

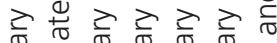

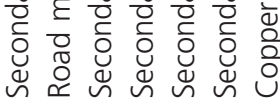

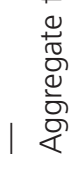

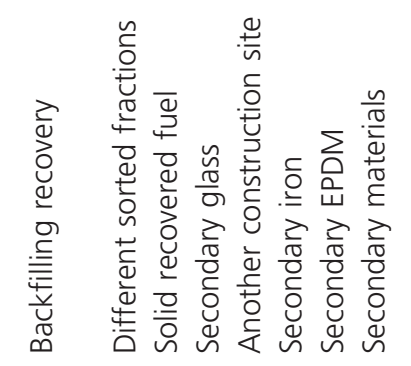

뭉

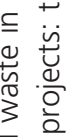

흄

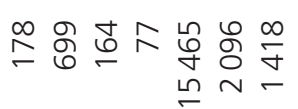

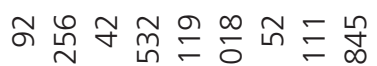

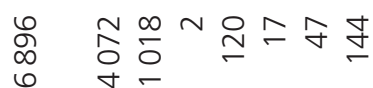

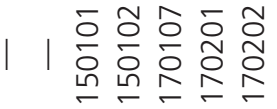

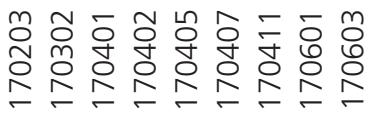

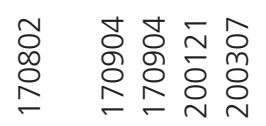

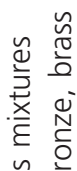

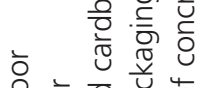

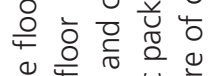

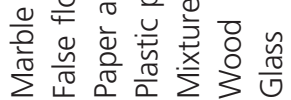

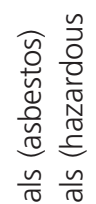

离

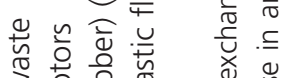

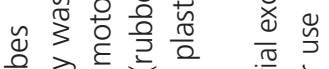

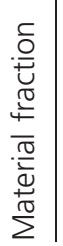

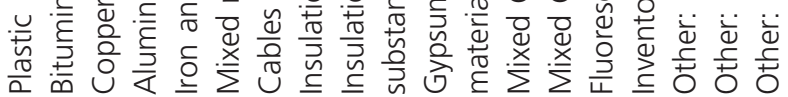

这离焉

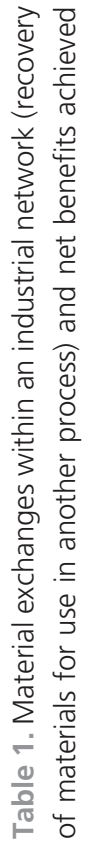




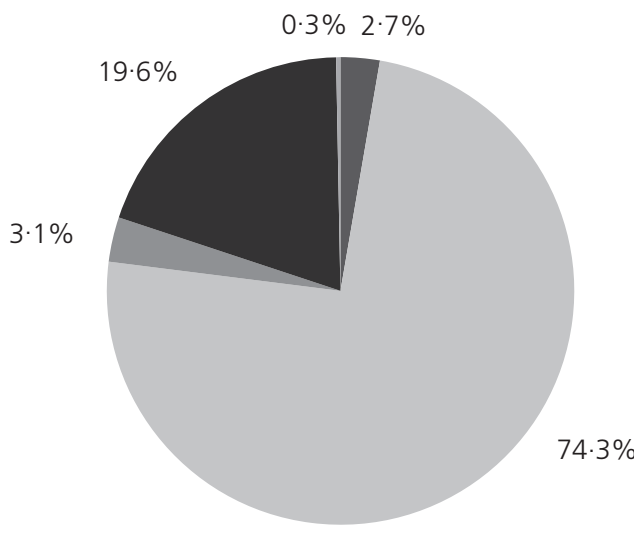

Reuse $(2 \cdot 7 \%)$

Material recycling (74.3\%)

Energy recycling (3.1\%)

Backfilling (recovery) (19.6\%)

Landfill (0.3\%)

Reuse and recycling rate $=77.0 \%$ (across both projects)

Figure 5. Percentages of waste according to disposal options for both projects

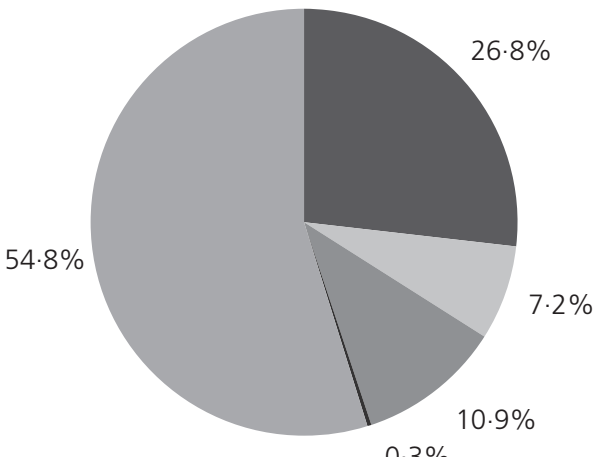

Diverted from landfill (26.8\%)

Diverted from incineration (7.2\%)

Diverted from sorting plant (10.9\%)

- Insulation materials (asbestos) (0.3\%)

Mixture of concrete, bricks, etc. and mixed CDW (54.8\%)

Figure 6. Percentages of waste diverted from landfill, incineration and sorting plants for both projects

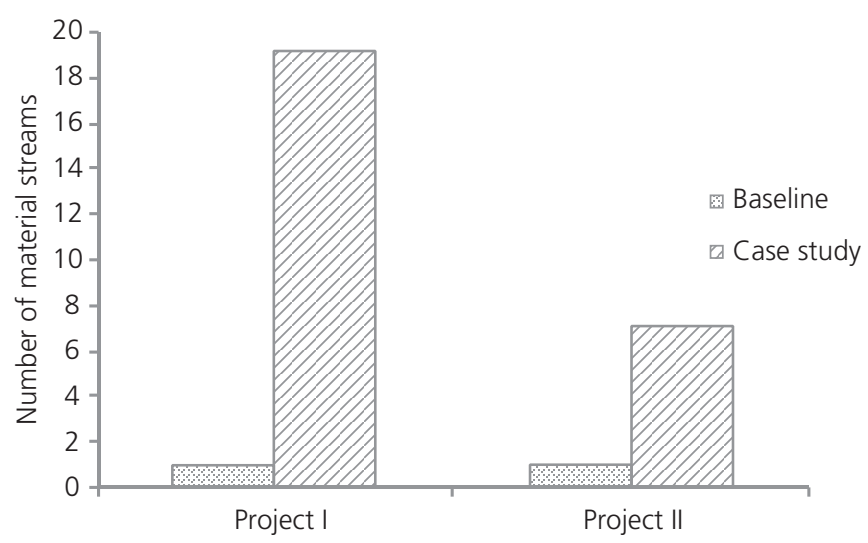

Figure 7. Absolute number of material streams separated directly on site 


\subsection{Environmental assessment}

Through the implemented concept, it was possible to decrease the environmental impacts of logistics processes compared with the baseline scenario in both projects. As shown in Table 2 for project I, a total quantity of $33467 \mathrm{t}$ of CDW was produced during the construction period (Tischer et al., 2013a). Of this, $997 \mathrm{t}(3.0 \%)$ could be reused as material for other sites and 24364 t (72.8\%) recycled. Furthermore, 910 t (2.7\%) waste could be supplied to energy recovery schemes and $7095 \mathrm{t}$ $(21 \cdot 2 \%)$ waste collected on site for backfilling (recovery). As noted earlier, during the demolition and gutting phase, $111 \mathrm{t}$ $(0 \cdot 3 \%)$ of insulating material containing asbestos had to be separated and sent to landfill. In total, the reuse and recycling rate was $75 \cdot 8 \%$ by weight.

For project II, $4003 \mathrm{t}$ of CDW was estimated to be produced during construction (Table 3 ) and $3490 \mathrm{t}(87 \cdot 2 \%)$ of this was estimated to be recycled. Furthermore, $253 \mathrm{t}(6 \cdot 3 \%)$ waste would be supplied to energy recovery and $261 \mathrm{t}(6 \cdot 5 \%)$ waste would be collected on site for backfilling (recovery). In total, the reuse and recycling rate was estimated to be $87 \cdot 2 \%$ by weight.

\subsection{Economic assessment}

Detailed data collection and analysis by screening secondary data and interviewing people responsible for materials and waste management in each project resulted in a complete picture of the total costs for implementing resource-efficient construction logistics. The main results were as follows (Figures 8 and 9). In total, the cost of construction logistics was $€ 4514262$ in project I. Compared with the baseline scenario of $€ 5194899$, this represents a decrease of $13 \cdot 1 \%$. A similar reduction was found for project II: a reduction of $10 \cdot 6 \%$ from $€ 2349462$ calculated for the baseline scenario to $€ 2099744$ in the case study.

In order to assess the materials efficiency of the logistics of disposal on site for each of the projects as described in Section 2.4, the relative costs of the logistics of disposal were calculated as

in project $\mathrm{I}, 132 \cdot 6 € / \mathrm{t}$ in the baseline scenario and $112 \cdot 3 € / \mathrm{t}$ in the case study

in project II, $299 \cdot 6 € / \mathrm{t}$ in the baseline scenario and $237 \cdot 2 € / \mathrm{t}$ in the case study (Figure 10).

\subsection{Eco-efficiency}

In addition to the analysis of environmental impacts, based on the results of the economic assessment it could be shown that material resource efficiency (measured as eco-efficiency) increased on the downstream side for each project within the logistics of disposal: in project I by $43 \%$ from $0.0047 \mathrm{t} / €$ to $0.0067 \mathrm{t} / €$ and by $68 \%$ in project II from $0.0022 \mathrm{t} / €$ to $0.0037 \mathrm{t} / €$ (Figure 11).

\section{Conclusion}

The aim of the research described in this paper was to increase material resource efficiency on construction sites by improving the logistics of delivery and especially the logistics of disposal, thus enabling the implementation of an industrial network around two selected construction sites in Germany. The main results are as follows.

\begin{tabular}{|c|c|c|c|c|c|c|c|c|}
\hline Waste fraction & EWC No. & Total: t & Reuse: $t$ & $\begin{array}{l}\text { Material } \\
\text { recycling: } t\end{array}$ & $\begin{array}{l}\text { Energy } \\
\text { recovery: } t\end{array}$ & $\begin{array}{l}\text { Backfilling } \\
\text { (recovery): } \mathrm{t}\end{array}$ & Landfill: t & $\begin{array}{l}\text { Reuse and } \\
\text { recycling } \\
\text { rate: \% }\end{array}$ \\
\hline $\begin{array}{l}\text { Paper and cardboard } \\
\text { packaging }\end{array}$ & 150101 & $93 \cdot 6$ & - & $93 \cdot 6$ & - & - & - & $100 \cdot 0$ \\
\hline Plastic packaging & 150102 & $16 \cdot 4$ & - & $16 \cdot 4$ & - & - & - & $100 \cdot 0$ \\
\hline $\begin{array}{l}\text { Mixture of concrete, bricks, } \\
\text { tiles and ceramics }\end{array}$ & 170107 & $1708 \cdot 2$ & - & $1708 \cdot 2$ & - & - & - & $100 \cdot 0$ \\
\hline Wood & 170201 & $210 \cdot 6$ & - & $210 \cdot 6$ & - & - & - & $100 \cdot 0$ \\
\hline Mixed metals & 170407 & $52 \cdot 7$ & - & $52 \cdot 7$ & - & - & - & $100 \cdot 0$ \\
\hline $\begin{array}{l}\text { Insulation materials } \\
\text { consisting of or containing } \\
\text { dangerous substances }\end{array}$ & 170603 & $41 \cdot 0$ & - & $41 \cdot 0$ & - & - & - & $100 \cdot 0$ \\
\hline $\begin{array}{l}\text { Gypsum-based construction } \\
\text { materials }\end{array}$ & 170802 & $617 \cdot 8$ & - & $617 \cdot 8$ & - & - & - & $100 \cdot 0$ \\
\hline Mixed CDW & 170904 & $1263 \cdot 6$ & - & $750 \cdot 1$ & $252 \cdot 7$ & $260 \cdot 7$ & - & $59 \cdot 4$ \\
\hline Total & & $4003 \cdot 7$ & - & $3490 \cdot 2$ & $252 \cdot 7$ & $260 \cdot 7$ & - & $87 \cdot 2$ \\
\hline
\end{tabular}


Industrial network design by

improving construction logistics

Tischer, den Boer, Williams and

Curran

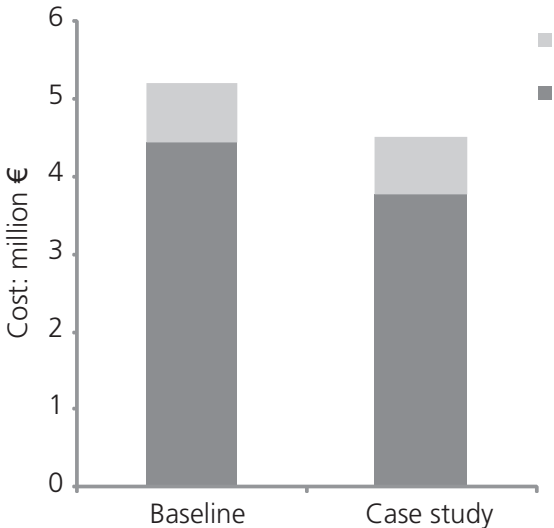

Figure 8. Cost of construction logistics for project I

(a) Working with the owner and the main contractors on each site, the concept of efficient construction logistics could be successfully implemented. The actions undertaken were

(i) selecting downstream companies to use residues from construction process as raw materials in their own production

(ii) separating residues already on site into different material fractions

(iii) optimising the transportation of materials to and from installation points on site

(iv) ensuring just-in-time delivery.

(b) The total number of material streams separated directly on site could be increased from 1 to 19 fractions in project I (refurbishment) and from 1 to 7 in project II (new construction).

(c) In total across both projects, $10036 \mathrm{t}$ materials could be

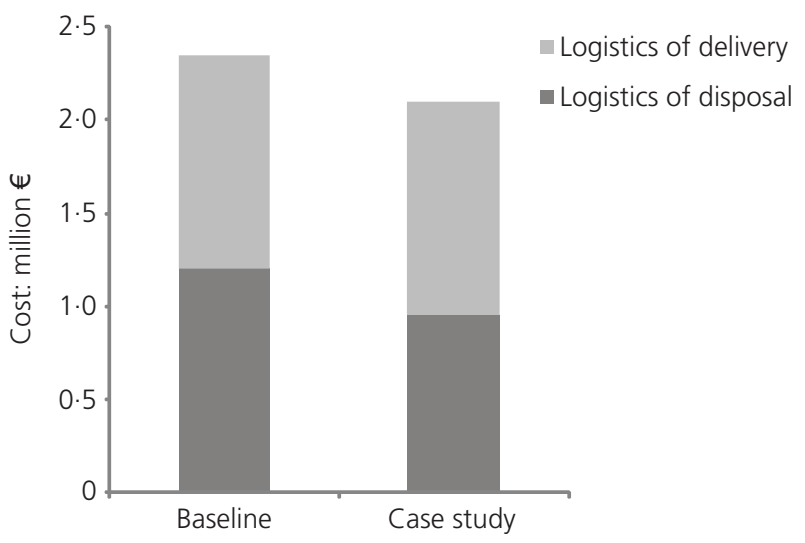

Figure 9. Cost of construction logistics for project II

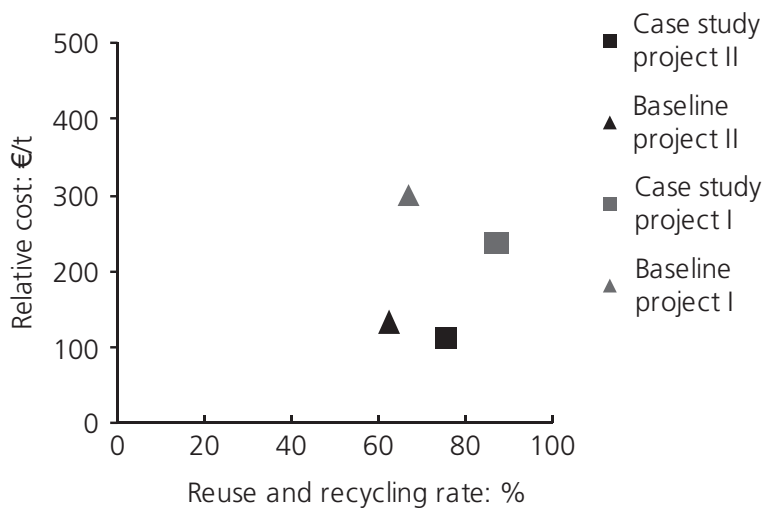

Figure 10. Relative cost of logistics of disposal compared with the reuse and recycling rate for both projects

diverted from landfill, $2685 \mathrm{t}$ from energy recovery and $4093 \mathrm{t}$ materials from sorting plants.

(d) The reuse and recycling rate could be increased from $62 \%$ to $76 \%$ in project I and from $67 \%$ to $87 \%$ in project II.

(e) By implementing the logistics approach, the calculated total logistics costs reduced in project I by $13 \%$ compared with the baseline. In project II, the total costs could be decreased by $11 \%$ compared with the baseline scenario.

(f) Material resource efficiency was calculated to increase on the downstream side by $43 \%$ for project I and $68 \%$ for project II.

The results obtained in this study highlight the benefits of efficient construction logistics and could be used to implement and support the idea of establishing an industrial network around any site. However, successful implementation of such a concept can only be achieved if the site project partners, the design team, all construction companies and especially the building owner, are equally determined to proceed in this way.

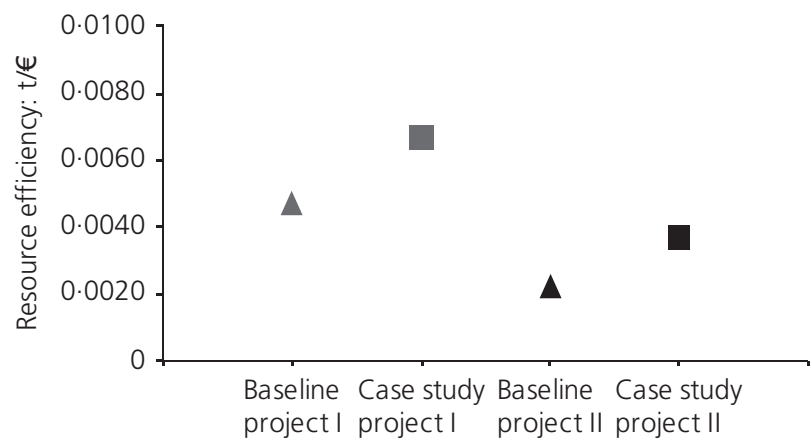

Figure 11. Resource efficiency of construction logistics of disposal for both projects 
Compared with the construction industry status quo, the approach can lead to environmental and economic benefits on site and thus to an increase of productivity of logistic aspects on the downstream side.

A major limitation of the research was that only two construction projects were investigated. It remains for future research to verify if the results can be generalised. For this, further case studies of praxis examples are necessary. Additionally, it would be interesting to know whether, and if so how, the concept of efficient construction logistics would influence the successful implementation of an industrial network from the upstream point of view, measured with quantitative, certain data and information. A complete picture of the establishment of an industrial network around a construction site could thus be drawn and assessed.

\section{Acknowledgement}

The authors are grateful for funding received from the European Community's Seventh Framework Programme (FP7/2007-2013) under grant agreement 226752, which enabled this research to be concluded.

\section{REFERENCES}

Baxter P and Jack S (2008) Qualitative case study methodology: study design and implementation for novice researchers. The Qualitative Report 13(4): 544-559.

BBD (Bundesrechtsvordnung der Bundesrepublik Deutschland) (2003) Gewerbeabfallverordnung (GewAbfV) Inkrafttreten am 01.02.2003. BBD, Berlin, Germany (in German).

Boenert L and Blömeke M (2003) Logistikkonzepte im Schlüsselfertigbau zur Erhöhung der Kostenführerschaft. Bauingenieur 78(6): 277-283 (in German).

Brodersen J, Juul J and Jacobsen H (2002) Review of Selected Waste Streams: Sewage Sludge, Construction and Demolition Waste, Waste Oils, Waste from Coal-fired Power Plants and Biodegradable Municipal Waste. See http://www.eea.europa.eu/publications/ technical_report_2001_69 (accessed 15/07/2013).

Cheng EWL, Li H, Love PED and Irani Z (2001) Network communication in the construction industry. Corporate Communications 6(2): 61-70.

Ebel G (2012) Vorgehensmodell für die Anforderungsanalyse in der Baulogistik. Dissertation, Technische Universität Dortmund, Dortmund, Germany (in German).

EEA (European Environment Agency) (2010) The European Environment, State and Outlook 2010 - Material Resources and Waste. See http://www.eea.europa.eu/soer/europe/ material-resources-and-waste (accessed 15/07/2013).

EEA (European Environment Agency) (2012) Material Resources and Waste-2012 Update The European Environment State and Outlook 2010. See http://www.eea.europa.eu/publications/ material-resources-and-waste-2014 (accessed 15/07/2013).
Eisenhardt KM (1989) Building theories from case study research. Academy of Management Review 14(4): 532-550.

Ellram L (1996) The use of the case study method in logistics research. Journal of Business Logistics 17(2): 93-138.

Goetz A and Höchsmann C (2010) Baulogistik - Modell eines eigenständigen Dienstleistungsgewerkes für Großbaustellen am Beispiel des Bauprojektes 'PalaisQuartier' in Frankfurt am Main. Wettbewerbsbeitrag Logistics Service Award 2010. See http://www.architekten24.de/mediadb/news/ 12271/bauserve_Bewerbung_lsa.pdf (accessed 15/07/2013).

Hasenclever T, Horenburg T and Höppner G (2011) Logistikmanagement in der Bauwirtschaft. In Digitale Baustelle - innovativer Planen, effizienter Ausführen, 1st edn (Günther W and Borrmann A (eds)). Springer, Berlin, Germany, pp. 205-287 (in German).

Huppes G and Ishikawa M (2005) Eco-efficiency and its terminology. Journal of Industrial Ecology 9(4): 43-46.

Jang H, Russel JS and Yi JS (2003) A project manager's level of satisfaction in construction logistics. Canadian Journal of Civil Engineering 30: 1133-1142.

Kim I and Min H (2012) Green supply chain research: past, present, and future. Logistics Research 4(1-2): 39-47.

Krauß S (2005) Die Baulogistik in der schlüsselfertigen Ausführung. Dissertation, Universität Stuttgart, Stuttgart, Germany (in German).

Meredith J (1998) Building operations management theory through case and field research. Journal of Operations Management 16: 441-454.

Mirata M and Pearce R (2006) Industrial symbiosis in the UK. In Industrial Ecology and Spaces of Innovation (Green K and Randles S (eds)). Edward Elgar, Cheltenham, UK, pp. 77-105.

Obersteiner G, Beigl A, Pertl A and Scherhaufer S (2013) Report on Assessments of Pilot Cases: Final Assessment. Deliverable 7.3 of the ZeroWindustrial Network Project. See http://www.zerowin.eu/ (accessed 15/07/2013).

Schach R and Schubert N (2009) Logistik im Bauwesen. Wissenschaftliche Zeitschrift der TU Dresden 58(1-2): 59-63 (in German).

Schwarzer EJ and Steininger KW (1997) Implementing nature's lesson: the industrial recycling network enhancing regional development. Journal of Cleaner Production 5(1-2): 47-56.

Tischer A and Gartmann A (2010) Implementing an industrial network in construction industry through efficient construction logistic. Proceedings of Going Green CARE Industrial Network INNOVATION 2010. Austrian Society for Systems Engineering and Automation, Vienna, Austria.

Tischer A, Besiou M and Graubner CA (2013a) Efficient waste management in construction logistics: a refurbishment case study. Logistics Research 6(4): 159-171.

Tischer A, Besiou M and Goetz A (2013b) Implementing 
construction logistics for inner-city construction projects: success drivers and challenges. In Proceedings of 2013 Hamburg International Conference of Logistics: Success Drivers of Logistics and Supply Chain Management, Hamburg, Germany (Kerste W, Blecker T and Ringle CM (eds)). Josef EUL Verlag, Lohmar-Köln, Germany, pp. 165-178.

Voigtmann J and Bargstädt HJ (2010) Construction logistics planning by simulation. In Proceedings of the 2010 Winter
Simulation Conference, Baltimore 2010 (Johansson B, Jain S and Montoya-Torres J (eds)). See http://www.informs-sim. org/wsc10papers/296.pdf (accessed 15/07/2013).

Williams ID and Curran T (2010) Aiming for zero waste: the ZeroWindustrial network approach. Waste Management World 11(4): 72-79.

Yin RK (2008) Case Study Research: Design and Methods. Sage, Thousand Oaks, CA, USA.

\section{WHAT DO YOU THINK?}

To discuss this paper, please email up to 500 words to the editor at journals@ice.org.uk. Your contribution will be forwarded to the author(s) for a reply and, if considered appropriate by the editorial panel, will be published as discussion in a future issue of the journal.

Proceedings journals rely entirely on contributions sent in by civil engineering professionals, academics and students. Papers should be 2000-5000 words long (briefing papers should be 1000-2000 words long), with adequate illustrations and references. You can submit your paper online via www.icevirtuallibrary.com/content/journals, where you will also find detailed author guidelines. 